\title{
WILLINGNESS TO PAY FOR ACCESSIBILITY UNDER THE CONDITIONS OF RESIDENTIAL SEGREGATION
}

\author{
Marko KRYVOBOKOV a,", Louafi BOUZOUINA ${ }^{\text {b }}$ \\ ${ }^{a}$ Laboratory of Transport Economics (LET), 14, avenue Berthelot, F-69363 Lyon Cedex 07, France \\ ${ }^{b}$ Laboratory of Transport Economics (LET), ENTPE, 3, rue Maurice Audin, F-69518 Vaulx-en-Velin, France
}

Received 29 September 2012; accepted 16 January 2013

\begin{abstract}
The hypothesis that different income groups have different willingness to pay for accessibility to the city centre is based on the standard monocentric model. This hypothesis is empirically tested with accessibility attributes in a hedonic model of apartment prices in the suburbs of the city of Lyon, France. The conditions of residential segregation are described, and apartment prices in the poor and the rich suburbs are analysed with regression techniques. Travel times to two urban centres are accounted for, as well as centrality and accessibility integral indexes. We found that in the selected areas the hypothesis is true. Spatial differences between the estimates for accessibility measures are significant. In more socially problematic areas, the willingness to pay for better accessibility is higher.
\end{abstract}

KEYWORDS: Accessibility; Bid-rent function; Hedonic regression; Apartment price; Residential segregation

REFERENCE to this paper should be made as follows: Kryvobokov, M.; Bouzouina, L. 2014. Willingness to pay for accessibility under the conditions of residential segregation, International Journal of Strategic Property Management 18(2): 101-115.

\section{INTRODUCTION}

Economic literature about urban segregation experienced rapid development since the first work of Kain (1968) on the difficulties of employment access for the inhabitants of American ghettos. Numerous case studies dealing with the question of neighbourhood effect test the impact of social polarisation or accessibility on unemployment, isolation, crime or school results in problematic districts of different cities and countries (Case, Katz 1991; Hoxby 2000; Bayer et al. 2008; Galster et al. 2008).

In France, the economic studies of segregation are more recent and mainly dated by the years 2000s (Fitoussi, Savidan 2003; Maurin 2004; Buisson, Mignot 2005). With several exceptions analysing geographic and ethnic origins (Pan Ké Shon 2010), this literature focuses on the socioeconomic dimensions to demonstrate the increasing inequalities between rich and poor neighbour-

\footnotetext{
* Corresponding author. E-mail: k_mark@ukr.net or mark.kryvobokov@let.ish-lyon.cnrs.fr
}

hoods and to measure their negative consequences on the economic, human and social capital of poor inhabitants, whose significant share is suffered from high unemployment (Bouabdallah et al. 2002; Choffel, Delattre 2003; Gaschet, Gaussier 2005; Gobillon, Selod 2004; Korsu, Wenglenski 2010). Most of these studies confirm the hypothesis that the unemployment of poor residents is partially caused by poor accessibility to jobs (especially to low-skilled jobs) and high poverty rates. The two main reasons of poor employment accessibility in the Paris region are location in remote neighbourhoods with few jobs and low car-ownership rate (Korsu, Wenglenski 2010). In their analysis of the Lyon, Marseille, and Lille urban agglomerations, Mignot et al. (2009) highlight the point that though some recent studies report little inequality in daily mobility since households have access to cars, at the same time inequality increases for those without car.

The growing interest of academic research to residential segregation in France can be explained by a complicated reality including violence and 
urban riots, which needs to be adequately understood before elaboration of a competent policy by decision-makers. The first urban riots in France took place in the eastern suburbs (banlieues) of Lyon: Vénissieux in 1981 and Vaulx-en-Velin in 1990, while the last one happened in 2005 and called "the suburb crisis" touched many French cities. This situation has often been interpreted as a fiasco of the integration policy in neighbourhoods mainly populated by immigrants and their descendants. While French law prohibits collecting statistical data on racial and religious principles, some studies based on nationality of origin demonstrate that ethnic segregation is often superimposed with socio-economic segregation (Fitoussi, Savidan 2003). Focusing on life conditions in the disadvantaged suburbs, Pan Ké Shon (2010) highlights the rise in ethnic segregation and simultaneous reduction in income segregation between two most recent censuses. While the socially best-equipped residents, mainly French nationals, leave problematic neighbourhoods, most of the younger arrivals, who are North Africans and Black Africans, have "poor social characteristics" (Pan Ké Shon 2010). However, he rejects the idea that the high concentration of immigrants is the result of self-segregation, because what is observed is not a "White flight", but rather "all run" (Pan Ké Shon 2009). Not taking into account discrimination, which is difficult to quantify, the problems of the banlieue population are mainly socio-economic, such as the access to housing market and employment market under the constraints of income, housing prices and job accessibility.

The theory of spatial mismatch (Kain 1968; Cutler, Glaeser 1997) first and foremost describes the problems connected with the social polarisation of disadvantaged population in the central parts of American cities and their poor accessibility to jobs in outlying subcentres. In French cities, most of jobs remain concentrated in the centre, while the most segregated neighbourhoods are situated in periphery (Bouzouina 2008). In such neighbourhoods, public investments are often taking place aiming at improving accessibility as well as economic and residential attractiveness in order to reach social and functional diversity. Transport projects are based on two leverages: land use development and transport cost reduction by speed increase. These gentrification projects can however have the opposite consequences penalizing population in problematic neighbourhoods if the positive economic effect of diminishing transport cost is weaker then an increase in housing prices. This can lead to eviction of the poorest population henceforward incapable to pay more for improved accessibility.

In this paper we deal with residential segregation, accessibility and housing price. We test the hypothesis that accessibility is evaluated differently by different income groups. This hypothesis is based on the standard monocentric model of residential bid rent. We study empirically how accessibility is evaluated at housing market in areas with different social status. The goal of the paper is to contribute to the empirical understanding of accessibility measures as housing price determinants. The spatial trend in their evaluation is analysed in the Lyon suburbs populated by households mainly belonging to different income groups.

In order to find differences in the impacts of accessibility on housing prices among income groups of population, the following sampling strategy is applied. With the intention to study the phenomenon in extremely poor and extremely rich areas, two extremums are selected geographically. The first one includes two of the poorest municipalities, while the second one - two rather prosperous areas. We are limited by the objective data constraints. In French urban areas, the poorest households live in apartment blocks and thus the apartment segment of housing market should be analysed for the richest households as well despite the fact that a big share of the rich lives in detached houses. Therefore, instead of looking for the areas with the highest overall average income, we choose the richest municipalities among those with representative samples of apartment sales.

The remainder of the paper is organised as follows. The next Section is a short literature review. Section 3 describes the standard bid-rent functions in a monocentric city for two income groups of population: the rich and the poor. The hypothesis that accessibility is evaluated differently is empirically tested in Section 4, which includes data description and hedonic regression models applying the methodologies of geographically weighted and spatial error regressions. The final Section concludes.

\section{LITERATURE REVIEW}

One part of the literature analysing the links between accessibility and housing price in disadvantaged neighbourhoods deals with gentrification issues focusing on the renovation urban policy. In the economic literature, the determinants of renovation and land use development can be grouped into the three following factors: first, those connected with the economic laws of location resulting from the monocentric model, they deal mainly 
with income, transport cost and housing demand; second, housing age and quality; and third, neighbourhood characteristics and population behaviour (Helms 2003). The third group confirms the impact of accessibility to the centre, especially by public transport: "Accessibility to the CBD matters: improvement is more likely in areas that are close to downtown and well-served by mass transit" (Helms 2003: 496).

In real estate valuation, accessibility issues are under close attention at least since the von Thünen theory has been elaborated in the first half of the $19^{\text {th }}$ century. Accessibility to the city centre is in the core of the Alonso (1964) bid-rent model. In their residential location choice, households make a trade-off between housing price and transport cost in the bid-rent function representing maximal land price per unit, which an individual is ready to pay in each part of a city. This is the principal issue of the standard model of urban economics (Alonso 1964; Mills 1967; Muth 1969). Thus, households can either reside in the centre close to employment opportunities or prefer peripheral location with more spacious accommodation and pay higher transport cost. The model does not propose an analytical solution concerning the spatial distribution of population consisting of different income groups, but implicitly considers that rich population is more sensible to consume accommodation that leads to concentration of the poor in the centre.

However, the centre cannot concentrate all jobs. Polycentric patterns of modern cities have been recognised (McDonald 1987; McMillen, Lester 2003) and incorporated into hedonic analyses of real estate prices and rents (McDonald, McMillen 1990; McMillen 1996; Sivitanidou 1996). Urban form depends on the scale of the analysis; this point can be illustrated in the analyzed geographical context. According to Bouzouina (2008), the Lyon urban area is monocentric, with one centre in Lyon and Villeurbanne. Kryvobokov (2010) found fifteen candidates for service employment subcentres within Lyon and Villeurbanne.

Wheaton (1977) with the San Francisco data demonstrated that there exist substantial differences among income groups in the value of travel time and the demand for land, but these compliment one another to yield bid-price gradients that appear quite similar. Also, he found that although the value of travel time increases significantly with income, it is totally overshadowed by the fixed money costs of travel. In France, the hypothesis of identical bid-rent functions has not yet been verified (Goffette-Nagot et al. 2000). Not all the cities are monocentric (Anas et al. 1998), and the strength of housing market is sometimes weaker than that of generalised transport cost (Glaeser et al. 2008). The distinction between transport cost by public transport and by car is central in the explication of socio-spatial distribution (LeRoy, Sonstelie 1983).

Ross et al. (2011) have shown the inability to fit more than two distance variables into hedonic regression model arguing that two points in space triangulate the optimal position by fundamental geometry. Beside distances "as the crow flies", network distances and travel times to urban centres, integral centrality and accessibility measures are applied in hedonic modelling of housing values. The centrality concept is an objective one; it takes into account the location of opportunities and potential access to them (e.g. Krizek 2005). The accessibility measure in the interpretation of Thériault et al. $(2005,2007)$ is subjective one, based on trip duration thresholds (Kim, Kwan 2003); it is the ease with which persons, living at a given location, can move in order to reach activities and amenities which they consider as important.

Thériault et al. (2007) analyse links among mobility, accessibility and housing markets and pay attention to perceptual issues, which depend on self-valuation of time and ability and willingness to pay a premium for better home location. They argue that these values, ability and willingness related to specific constraints define a utility functions, which are somewhat different for each household and are likely to differ among social groups. Moreover, Thériault and colleagues speculate that it could be argued that in modern cities, social gradients are progressively prevailing over access factors as major price determinants. Thériault et al. (2007) calculate accessibility indexes for men and woman and find significant differences in centrality and accessibility estimates among house types in hedonic models. In our study we do not calculate different measures for population groups, but focus on differences in price premiums for the same attributes among different groups and locations.

\section{THE STANDARD MONOCENTRIC CITY MODEL FOR TWO INCOME GROUPS}

The monocentric city model has been proposed by Alonso (1964) and generalized in many ways by Mills (1967), Muth (1969) and Fujita (1989). A comprehensive overview can be found e.g. in Anas et al. (1998). 
While we deal with two income groups of households and with apartments, the following designations for the standard bid-rent model are used hereafter:

- $z_{r}, z_{p}$ - composite goods representing all consumer goods except housing and transport for the rich and the poor respectively;

- $A_{r}, A_{p}$ - apartment floor area for the two income groups;

- $u_{r}\left(z_{r}, A_{r}\right), u_{p}\left(z_{p}, A_{p}\right)$ - utilities from a composite good and apartment floor area for the two income groups;

- $T_{r}(x), T_{p}(x)$ - transport costs, which include the value of travel time, for households living $x$ units from the $\mathrm{CBD}$ and belonging to the two income groups;

- $W_{r}, W_{p}$ - exogenous incomes of households belonging to the two income groups.

Each household has an income, which covers its expenditures on the composite good, transport and apartment rent. The residential bid rent at location $x$ is the maximum rent per floor area unit that a rich or a poor household is able to pay and still receive utility $\bar{u}$ :

$b\left(x, \bar{u}_{r}\right)=\max _{z_{r}, A_{r}} \frac{W_{r}-z_{r}-T_{r}(x)}{A_{r}}$ s.t. $u_{r}\left(z_{r}, A_{r}\right) \geq \bar{u}_{r} ;$

$b\left(x, \bar{u}_{p}\right)=\max _{z_{p}, A_{p}} \frac{W_{p}-z_{p}-T_{p}(x)}{A_{p}}$ s.t. $u_{p}\left(z_{p}, A_{p}\right) \geq \bar{u}_{p}$.

By the envelope theorem, the slopes of the bidrent functions are:

$$
\begin{aligned}
& \frac{d b\left(x, \bar{u}_{r}\right)}{d x}=-\frac{T_{r}^{\prime}(x)}{A_{r}\left[W_{r}-T_{r}(x), \bar{u}_{r}\right]} ; \\
& \frac{d b\left(x, \bar{u}_{p}\right)}{d x}=-\frac{T_{p}^{\prime}(x)}{A_{p}\left[W_{p}-T_{p}(x), \bar{u}_{p}\right]},
\end{aligned}
$$

where: $A_{r}[\cdot], A_{p}[\cdot]$ are the solutions to the maximisation in (1). For brevity, the square brackets are not used hereafter. The ratio of the slopes of the bid-rent functions is the following:

$$
\frac{\frac{d b\left(x, \bar{u}_{r}\right)}{d x}}{\frac{d b\left(x, \bar{u}_{p}\right)}{d x}}=\frac{A_{p}}{A_{r}} \cdot \frac{T_{r}^{\prime}(x)}{T_{p}^{\prime}(x)} .
$$

Transport cost for the rich and the poor can be the same. It means that they not only use the same amount of gasoline per distance unit for their cars or the same tickets for public transport, but also evaluate their time, comfort, safety, etc. in the same manner. If this is the case, i.e. $T_{r}(x)=T_{p}(x)$, then:

$$
\frac{d b\left(x, \bar{u}_{r}\right)}{d b\left(x, \bar{u}_{p}\right)}=\frac{A_{p}}{A_{r}},
$$

or the ratio of the bid-rent functions of the two income groups is inversely proportional to their apartment floor areas, which are the maximisation solutions. When $A_{r}>A_{p}$, i.e. the rich have larger apartments:

$$
\frac{d b\left(x, \bar{u}_{r}\right)}{d b\left(x, \bar{u}_{p}\right)}<1 .
$$

If $T_{r}(x) \neq T_{p}(x)$, the ratio $\frac{T_{r}^{\prime}(x)}{T_{p}^{\prime}(x)}$ from (3) can be less than unity if the additional transport cost for the rich located a small additional distance $d x$ from the CBD is lower than for the poor. If both conditions $A_{r}>A_{p}$ and $T_{r}^{\prime}(x)<T_{p}^{\prime}(x)$ take place, the inequality (5) is true again.

We should note that both assumptions contradict a standard view that the value of travel time increases with income. However, it is not always easy to grasp the difference in its evaluation by income groups. First, it can be overshadowed by fixed travel costs (Wheaton 1977). Second, different car-ownership rates for social groups (Korsu, Wenglenski 2010) and thus different modes of travel can lead to shorter travel times for the rich. What is probably more important is that location amenities (which are not only the proximity to the CBD) not presented in the aforementioned model can outweigh the travel time component of the location choice of high-income households.

Thus, ignoring location amenities and assuming that the rich prefer larger apartments and either the transport cost for both income groups are the same or the marginal transport cost for the rich is lower than for the poor, the bid-rent gradient for the rich is lower. In other words, under the mentioned conditions, with each additional distance unit from the CBD the bid-rent for the rich decreases slower than for the poor. It is worth to repeat again that in this simple derivation the difference among income groups is mainly manifested in apartment floor area units, while the categories of geographical peculiarities, prestige, racial composition, etc. are ignored. We will deal with some of them in the empirical exercise in the next Section. 


\section{THE EMPIRICAL MODEL}

\subsection{The study area and data}

The Lyon metropolitan area is the second largest by population in France. In 2005, its population counted about 1.75 million inhabitants. The centre of the agglomeration is formed by the adjacent cities of Lyon and Villeurbanne (Fig. 1) with total population of more than 600 thousand inhabitants.

In the Lyon agglomeration, the share of car in mode choice composes $66.0 \%$, while those of public transport 12.6\% (Mignot et al. 2009). The rich and the poor households in this study are determined as occupying the highest $20 \%$ and the lowest $20 \%$ in the income range respectively. According to the household travel survey conducted in the agglomeration in 2006, the rich and the poor have the same number of home-to-shop trips per person, and trip duration is only $4 \%$ lower for the poor. The maximum difference between the poor and the rich for trip duration is observed for home-to-work trips, and it is only $7 \%$.

It is a well-known phenomenon that western suburbs of Lyon are prosperous, while eastern ones are poor. The selected four municipalities are Sainte-Foy-lès-Lyons and Oullins in the west and Vénissieux, and Vaulx-en-Velin in the east (Fig. 1).

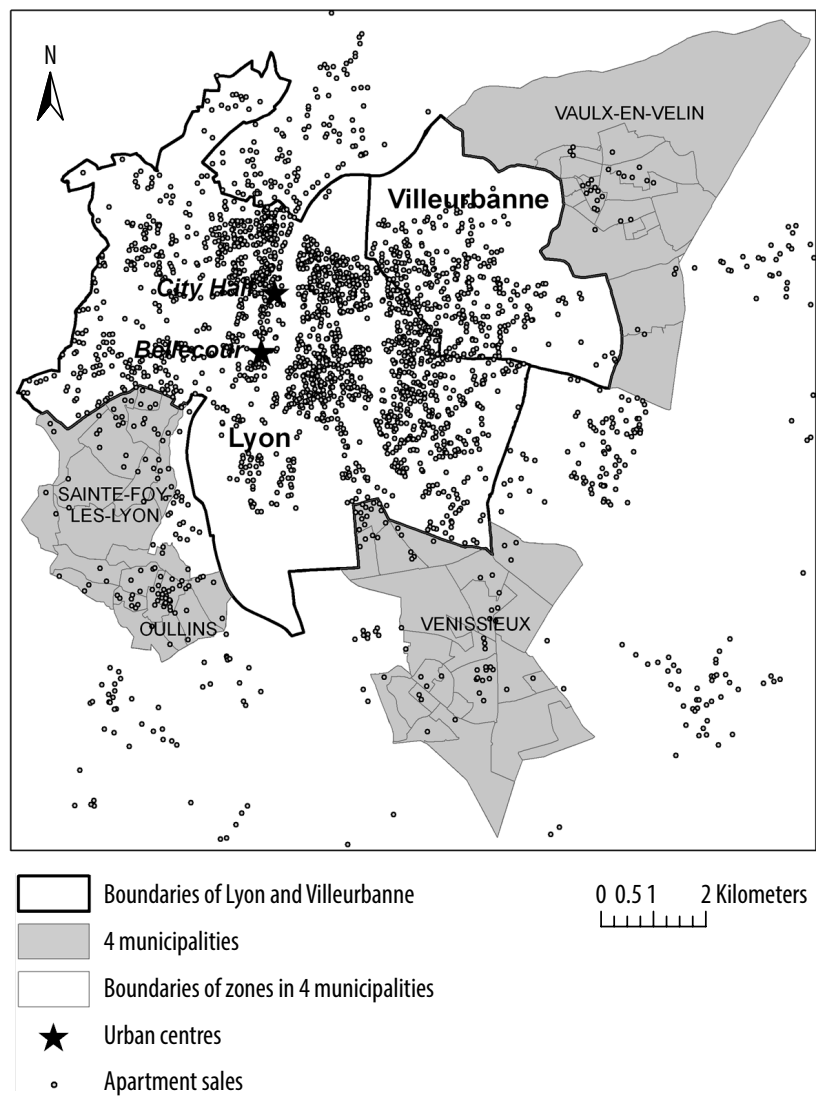

Fig. 1. The four suburbs and apartment sales
All these municipalities are located in the Greater Lyon, or the first ring of suburbs, and experienced quite similar general demographic trends: positive dynamics till the 1980s, slight fall in the 1980s and 1990s (which was sharper in Vaulx-en-Velin and Vénissieux) and modest increase in recent years.

In the poor eastern suburbs, where the population is mainly formed by immigrants and their descendants, ethnic dimension overlays with socioeconomic one (Fitoussi et al. 2004), but it plays an important role in the perception of the area including the stigmatisation process. According to the last census in 1999, in the eastern Lyon banlieues the share of foreign nationals reached $22 \%$, while in some rich neighbourhoods in more western locations it composed only $3 \%$. The analysis of the demographic evolution of foreigners in disadvantaged neighbourhoods and their residential migration demonstrates the behaviour patterns, which are similar to the population average. Foreigners leave or avoid these neighbourhoods as well as French nationals, despite difficulties of relocation specific to them. This "all run" reality (Pan Ké Shon 2009), which is seldom demonstrated explicitly, according to Bouzouina (2008) confirms the socio-economic dominance in the segregation process.

Table 1 contains the statistical description of the four municipalities. The demographic data is referred to 2005, the employment to 2006, and car-ownership rates and incomes to 1999. In the eastern banlieues, especially in Vaulx-en-Velin, the average number of persons in household is higher and car-ownership ratio is lower. Lower percentages of high-income households and much higher percentages of low-income population live in the eastern suburbs (note that in 2008, by average household income Vaulx-en-Velin occupied the $31286^{\text {th }}$ place among 31604 French municipalities with more than 50 households). The most visible contrast however is highlighted by the two indicators of social insecurity: unemployment rate among active population and the percentage of households living in social housing. The unemployment rate in Vaulx-en-Velin is three times higher than in Sainte-Foy-lès-Lyons.

According to legislation, municipalities in France are obliged to have not less than $20 \%$ of their housing stock social. In fact, almost the same percentage of households lives in social housing. Based on several sources, Bouzouina (2009) and Pan Ké Shon (2010) argue that implementing this policy, decision-makers in France can reserve the least-desirable accommodations for the poor and immigrants and thus contribute to segregation. 
The described four suburbs are the examples of the uneven distribution of social housing stock. In the western suburbs, this percentage is lower than 0.20 , especially in Sainte-Foy-lès-Lyons, while in the eastern banlieues half of population lives in social housing (Table 1).

Income disparities and social contrasts between the selected suburbs clearly demonstrate that in terms of attractiveness and prestige, "bourgeois" western areas are far surpassing their eastern counterparts. Moreover, both Vaulx-en-Velin and Vénissieux have an image of well-known highpoverty banlieues. The following quotation from Korsu and Wenglenski (2010) about the public view of problematic areas in general can be exploited to describe both: "many people associate such neighbourhoods with violence, criminality, unwillingness to work, alcohol and drug addiction, etc." (ibid: 2285).

In respect to public transport, the socialist governance of the Lyon agglomeration tries to favour eastern suburbs. The most expensive investments in public transport, such as the extensions of metro and tramway lines, take place to the east from Lyon, including Vénissieux and Vaulx-en-Velin, while in the western suburbs these types of public transports do not exist. In the eyes of many Lyonnais, the relative underdevelopment of public transport in western suburbs is to same degree a deliberate policy supporting their higher standing. A good illustration of the Not-In-My-BackYard principle of the wealthy population is their protest (though unsuccessful) in the 1990s against prolongation of the metro line directly linking Vénissieux with north-western Lyon.

We use the data on about 10,000 apartment sales selected randomly from all sales in the central part of the Lyon metropolitan area in the period 1997-2008. These data on sale prices and apartment attributes were provided by Perval, who collects information about real estate transactions in France. After deleting observations with incomplete data, 4,362 apartments remained. The definition of variables and descriptive statistics are given in Table 2. It contains information about transactions, as well as on apartment attributes and location attributes. It does not include the number of rooms, because the cardinal discrete variables for them are highly correlated with apartment area and are not significant if included in the hedonic model. Many observations contain no data about the number of parking places, number of cellars, and quality of view; therefore the specific dummy variables are created. In the sample, $28 \%$ of the apartments were new, sold in a primary market.

The location variables in Table 2 include the percentages of high-, middle-, and low-income households, and dummies for location in one of four ad hoc districts. The four ad hoc districts are quite large, but relatively homogenous territories, divided by water frontiers and the boundaries of the urbanised area. District 1 includes the most central part of Lyon between the Rhône and the Saône. District 2 is an urbanised area on the left bank of the Rhône. District 3 is an urbanised area on the right bank of the Saône. District 4 is the less urbanised territory.

Table 2 contains the following accessibility measures: travel times by car, travel times by public transport, tertiary employment centrality index, and tertiary employment accessibility index. The origin-destination (O-D) matrix of travel times is estimated for morning peak with the MOSART transportation model developed with the VISUM software (Bonnafous et al. 2011). It is a four-step model, which forecasts transportation demand. We account for the travel times to the Lyon City Hall and to Bellecour, which is the main public transport junction located in the central part of Lyon. Both City Hall and Bellecour are among the fifteen (sub) centres identified with a regression of service employment density on travel time (Kryvobokov 2010),

Table 1. Socio-demographic description of the four suburbs

\begin{tabular}{|c|c|c|c|c|}
\hline Attribute & Sainte-Foy-lès-Lyons & Oullins & Vénissieux & Vaulx-en-Velin \\
\hline Population & 22,616 & 26,426 & 57,566 & 40,241 \\
\hline Households & 9,208 & 12,032 & 21,965 & 14,293 \\
\hline Persons in household & 2.46 & 2.20 & 2.62 & 2.82 \\
\hline Cars to households ratio & 1.25 & 1.01 & 0.95 & 0.87 \\
\hline Cars to population ratio & 0.51 & 0.45 & 0.37 & 0.31 \\
\hline Percentage of high-income households & 0.17 & 0.14 & 0.11 & 0.10 \\
\hline Percentage of low-income households & 0.21 & 0.25 & 0.33 & 0.37 \\
\hline Percentage unemployed & 0.07 & 0.09 & 0.18 & 0.21 \\
\hline Percentage of households in social housing & 0.07 & 0.15 & 0.50 & 0.51 \\
\hline
\end{tabular}


Table 2. Descriptive statistics of apartment attributes

\begin{tabular}{|c|c|c|c|c|c|}
\hline Variable & Description & Mean & Minimum & Maximum & Std. deviation \\
\hline Price & Transaction price, Euro & $122,507.50$ & 10,965 & $1,120,000$ & 77,200 \\
\hline Year97-Year08 & Dummies for year of transaction & $0.04-0.13$ & 0 & 1 & $0.20-0.34$ \\
\hline Area & Apartment area, square metres & 68.94 & 8 & 301 & 28.12 \\
\hline Bath1-Bath3 & Dummies for number of bathrooms & $<0.01-0.93$ & 0 & 1 & $0.05-0.25$ \\
\hline ParkUn & $\begin{array}{l}\text { Dummy for cases with no data } \\
\text { about parking places }\end{array}$ & 0.26 & 0 & 1 & 0.44 \\
\hline Park0-Park3 & Dummies for number of parking places & $<0.01-0.49$ & 0 & 1 & $0.06-0.50$ \\
\hline FloorGr & Dummy for ground floor & 0.13 & 0 & 1 & 0.33 \\
\hline Floor 1 & Dummy for storey 1 & 0.18 & 0 & 1 & 0.39 \\
\hline Floor2_4 & Dummy for storey 2 to 4 & 0.49 & 0 & 1 & 0.50 \\
\hline Floor5_8 & Dummy for storey 5 to 8 & 0.18 & 0 & 1 & 0.38 \\
\hline Floor9+ & Dummy for storey 9 or more & 0.02 & 0 & 1 & 0.14 \\
\hline $\begin{array}{l}\text { Constr }<1850- \\
\text { Constr } 1992<\end{array}$ & Dummies for period of construction & $0.03-0.34$ & 0 & 1 & $0.17-0.47$ \\
\hline CondGood & Dummy for good state & 0.81 & 0 & 1 & 0.39 \\
\hline CondMed & $\begin{array}{l}\text { Dummy for state when some } \\
\text { maintenance is needed }\end{array}$ & 0.16 & 0 & 1 & 0.37 \\
\hline CondBad & $\begin{array}{l}\text { Dummy for state when renovation } \\
\text { is needed }\end{array}$ & 0.03 & 0 & 1 & 0.17 \\
\hline ViewNo & $\begin{array}{l}\text { Dummy for cases with no data } \\
\text { about view }\end{array}$ & 0.60 & 0 & 1 & 0.49 \\
\hline ViewGood & Dummy for view increasing value & 0.38 & 0 & 1 & 0.48 \\
\hline ViewBad & Dummy for view decreasing value & 0.02 & 0 & 1 & 0.13 \\
\hline Cellar0-Cellar2 & Dummies for number of cellars & $0.02-0.66$ & 0 & 1 & $0.13-0.47$ \\
\hline Garden & Dummy for existence of garden & 0.05 & 0 & 1 & 0.22 \\
\hline Terrace & Dummy for existence of terrace & 0.09 & 0 & 1 & 0.29 \\
\hline NewApartment & Dummy for new apartment & 0.28 & 0 & 1 & 0.45 \\
\hline$\%$ HighIncome & Percentage of high-income households & 12.55 & 4.34 & 28.77 & 2.91 \\
\hline$\%$ MidIncome & Percentage of middle-income households & 57.96 & 42.70 & 66.20 & 3.30 \\
\hline$\%$ LowIncome & Percentage of low-income households & 29.49 & 10.24 & 52.12 & 5.78 \\
\hline District1-District4 & Dummies for location in districts & $0.01-0.64$ & 0 & 1 & $0.12-0.48$ \\
\hline $\begin{array}{l}\text { TTBellecour, } \\
\text { TTCityHall }\end{array}$ & $\begin{array}{l}\text { Travel time to Bellecour, travel time } \\
\text { to City Hall in minutes }\end{array}$ & $11.00-21.73$ & 0.55 & $29.32-51.02$ & $4.99-11.16$ \\
\hline Centrality Index & Centrality index & $37.04-42.13$ & $12.15-13.45$ & 100.00 & $15.68-17.23$ \\
\hline Accessibility Index & Accessibility index & $63.07-64.70$ & $0.34-0.65$ & 100.00 & $25.63-27.47$ \\
\hline
\end{tabular}

similarly to McDonald and Prather (1994). The centrality and accessibility indexes are integral measures, which take account of tertiary employment. The former is gravity-based and the latter is a "subjective" measure based on satisfaction thresholds and fuzzy logic, for details see Appendix 1. Note that in Table 2 the geographical unit of analysis is not municipality, but smaller zone; that is why the percentages of income groups are lower and higher in comparison with Table 1, which represents municipalities. The zones are French statistical units IRISes (Ilots Regroupés pour l'Information Statistique) close to the tracts in the US.

Of this sample, we select four sub-samples from the analysed municipalities (Table 3). The average floor area is the highest in Sainte-Foy-lès-Lyons. Though this attribute is the lowest in Oullins, it becomes the second highest there if calculated per person using the average number of persons in household in municipality. According to the average price per square meter, Sainte-Foy-lèsLyons is again the leader. The minimum prices in the western suburbs are much higher than in the eastern ones, but relatively high average price and very high maximum in Vénissieux indicates a wide diversity of its housing stock. According to the $t$-test, Vaulx-en-Velin and Vénissieux, unlike western suburbs, have equal means for some attributes, e.g. the percentage of low-income households. 
Table 3. Apartment sales and accessibility in the four suburbs

\begin{tabular}{|c|c|c|c|c|}
\hline Attribute & Sainte-Foy-lès-Lyons & Oullins & Vénissieux & Vaulx-en-Velin \\
\hline \multicolumn{5}{|l|}{ Apartment sales } \\
\hline Number of sales & 84 & 100 & 97 & 54 \\
\hline Average floor area, $\mathrm{m}^{2}$ & 79 & 63 & 67 & 65 \\
\hline $\begin{array}{l}\text { Average floor area per average } \\
\text { number of persons, } \mathrm{m}^{2}\end{array}$ & 32.1 & 28.6 & 25.6 & 22.9 \\
\hline Average price per $\mathrm{m}^{2}$, Euro & 1,611 & 1,495 & 1,464 & 1,171 \\
\hline Minimum price per $\mathrm{m}^{2}$, Euro & 675 & 393 & 226 & 307 \\
\hline Maximum price per $\mathrm{m}^{2}$, Euro & 3,548 & 3,442 & 3,674 & 2,631 \\
\hline \multicolumn{5}{|l|}{ Accessibility by car } \\
\hline TTBellecour, minutes & 12.17 & 10.62 & 14.45 & 21.13 \\
\hline TTCityHall, minutes & 14.67 & 14.46 & 17.61 & 17.93 \\
\hline Centrality Index & 23.82 & 25.61 & 26.02 & 23.73 \\
\hline Accessibility Index & 28.20 & 33.94 & 30.77 & 23.10 \\
\hline \multicolumn{5}{|l|}{ Accessibility by public transport } \\
\hline TTBellecour, minutes & 28.61 & 29.42 & 29.73 & 35.41 \\
\hline TTCityHall, minutes & 31.48 & 33.33 & 35.08 & 32.69 \\
\hline Centrality Index & 20.84 & 20.03 & 23.13 & 21.74 \\
\hline Accessibility Index & 31.65 & 27.44 & 38.72 & 35.48 \\
\hline
\end{tabular}

Table 3 gives the average values of accessibility measures in the four municipalities. The eastern suburbs are located in general a bit farther from the two urban centres, but their indexes for public transport are higher at the expense of better developed network. The number of zones in Sainte-Foylès-Lyons, Oullins, Vaulx-en-Velin and Vénissieux are 10, 11, 18 and 24 respectively (see Fig. 1).

Besides using the sample of 4,362 observations, we extract the $20 \%$ most expensive apartments as well as the $20 \%$ cheapest apartments assuming that their buyers belong rather to the rich and the poor households respectively. These sub-samples called hereafter "expensive" and "cheap" are used in further analyses as proxies for the nongeographical submarkets for the rich and the poor, because it is difficult to find information about the income of the buyers of particular apartments in quantity sufficient to create a mass valuation model. For these two sub-samples the equality of means hypothesis is rejected for price, floor area, income levels and all accessibility measures. We admit that this division does not correspond to the rich and the poor household groups described above.

Furthermore, this sampling can be biased as some share of expensive apartments could be expensive just because of their large floor area, but cheap in respect to area unit. Some observations in the cheap segment, on the contrary, can be cheap due to small floor area, but have high price per area unit. In the context of the study, however, it is logical to assume that the poor are not able to buy expensive apartments even if their prices per area unit are low; while the rich prefer rather bigger accommodations. Therefore we suppose that our sampling strategy is less biased than it could be if it was based on price per square meter.

Correlation of apartment price per square meter (deflated to the initial year 1997) with accessibility measures are in line with our hypothesis: prices of more expensive apartments are less correlated with accessibility. If to consider the sales in Sainte-Foy-lès-Lyons and Vénissieux, their correlations behave similarly to the expensive and cheap sub-samples respectively. In Oullins and Vaulx-en-Velin, the sign of correlation coefficient is unstable. To understand the nature of these anomalies, econometric analysis is needed.

\subsection{Hedonic regression}

Applying the hedonic regression model of price as the dependent variable with willingness to pay for different attributes as independent variables, we continue the tradition proposed by Rosen (1974). If the supply of each characteristic is perfectly elastic, hedonic coefficients reveal demand for characteristics, though in most real-world contexts such a stringent maintained hypothesis is untenable (Malpezzi 2003). Hedonic price model is widely used in real estate research. The recent examples of its application to housing prices in France are 
Gouriéroux and Lafarrère (2009) and Baltagi and Bresson (2011).

There is no strong theoretical basis for substantiating the correct functional form of a hedonic regression (Halvorsen, Pollakowski 1981; Malpezzi 2003), but empirical tests found that the log-linear form has a number of advantages over the linear one (see e.g. Follain, Malpezzi 1980). More general and flexible form was proposed by Box and Cox (1964), but this function is beyond our current study.

In our specification, the dependent variable is the logarithm of Price. Among the independent variables described in Table 2, the logarithmic transformations of Area, \%MidIncome, \%HighIncome and travel times are used. The following attributes are the default values: Year97, Bath1, Park0, FloorGr, Constr1981_1991, CondGood, ViewGood, Cellar0 and District1.

First, an overall Ordinary Least Squares (OLS) model is built with 4,362 observations. Separate OLS models are created for the expensive and cheap apartment price segments; according to the $t$-test of equality of means of regressors, the null hypothesis is rejected for the majority of variables, including accessibility attributes and apartment floor area.

The observations from each of the four selected suburbs are exploited with separate OLS and Spatial Error models. In the latter, the error term is a function of the residuals in neighbouring areas. The geographically weighted regression methodology (GWR) is applied to all available sales to solve a regression equation in each observation point. For the OLS, a weighted standard error test (Schnare, Struyk 1976) shows that the four submarkets significantly reduce standard error in comparison with the pool model. The $t$-tests of equality of regression coefficients in the four submarkets give the following results: for accessibility measures, the null hypothesis is rejected in most cases, while for some other attributes, e.g. floor area, the coefficients are rather stable.

Each model is run eight times to examine the willingness to pay for each of the accessibility attributes in question, i.e. travel times to two urban centres and centrality and accessibility indexes, while each attribute is measured twice: for car and for public transport. Our hypothesis is that the richer population evaluates travel time to city centres differently from the poor. We examine as well if this is true in respect to the integral indexes. Under the conditions mentioned in Section 2, the absolute value of the estimate for the accessibility in the hedonic price model should be lower for the rich than for the poor.
Table 4 represents the estimated hedonic coefficients as well as model fit for OLS and GWR models. For the OLS models, the maximum variance inflationary factor (VIF) is also reported. All the significant coefficients of the models with TTBellecour by car are presented in Appendix 2, where the estimates of the expensive and cheap sub-samples and median GWR results are reported as well.

The three OLS models support our hypothesis. In the expensive segment, the absolute values of the estimates are always lower (often more than twice) than those in the overall model. In the cheap segment, the absolute values of the accessibility coefficients are always higher than those in the expensive segment. The negative effect of increase in travel time to Bellecour by public transport by $1 \%$ leads to price reduction in the cheap segment by $0.17 \%$, which is 2.8 times more than the price reduction in the expensive segment.

The four municipalities can also be analysed as submarkets, for which individual models are created. The same variables except construction years and some structural dummies are used in the OLS and Spatial Error (with a threshold distance weighting scheme) models for the submarkets. The Lagrange multiplier (LM) tests, applied for the OLS models, indicate high significance level of spatial errors in each of the four suburbs. The LM tests of the spatial lags are significant in Oullins and Vaulx-en-Velin, but due to difficulty in estimates interpretation, Spatial Lag model is not applied in this study. The estimates for the accessibility measures are presented in Appendix 3. However, this approach is rather useful to study the willingness to pay for accessibility measures within submarkets than the differences between them. Indeed, the estimates are insignificant and have "wrong" signs in Oullins and Vaulx-en-Velin, where the observations are less dispersed spatially than in Sainte-Foy-lès-Lyons and Vénissieux. The metro station in Vaulx-en-Velin opened in October 2007, by the end of the study period, and this fact can contribute to the "wrong" signs of accessibility variables. The effect of the new station on the price dynamics is however beyond the current study limits. In Sainte-Foy-lès-Lyons, the coefficients have "right" signs, but they are insignificant in most cases. The most intuitive results in Vénissieux with its dispersed observations are obtained with the OLS technique, but when spatial effect is accounted for, the accessibility measures calculated for car lose significance. Thus, within Vénissieux public transport has more impact on housing prices. 
Table 4. Estimates for the accessibility measures

\begin{tabular}{|c|c|c|c|c|c|c|c|c|}
\hline \multirow{2}{*}{$\begin{array}{l}\text { Model (OLS), } \\
\text { extraction (GWR) }\end{array}$} & \multicolumn{4}{|c|}{ Accessibility by car } & \multicolumn{4}{|c|}{ Accessibility by public transport } \\
\hline & 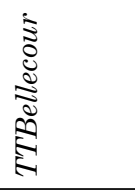 & 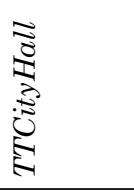 & 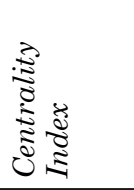 & 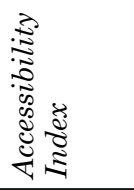 & 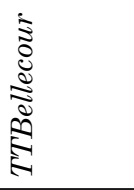 & 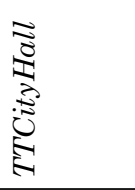 & 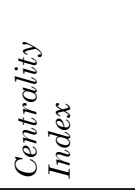 & 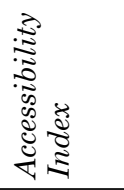 \\
\hline \multicolumn{9}{|l|}{ OLS* } \\
\hline $\begin{array}{l}\text { Overall, } \\
4,362 \text { obs., } \\
\text { adj. } \mathrm{R}^{2}=0.84-0.85 \\
\text { Max VIF }=6.27\end{array}$ & $\begin{array}{l}-0.224 \\
(<0.001)\end{array}$ & $\begin{array}{l}-0.278 \\
(<0.001)\end{array}$ & $\begin{array}{l}0.0085 \\
(<0.001)\end{array}$ & $\begin{array}{l}0.0051 \\
(<0.001)\end{array}$ & $\begin{array}{l}-0.223 \\
(<0.001)\end{array}$ & $\begin{array}{l}-0.228 \\
(<0.001)\end{array}$ & $\begin{array}{l}0.0078 \\
(<0.001)\end{array}$ & $\begin{array}{l}0.0049 \\
(<0.001)\end{array}$ \\
\hline $\begin{array}{l}\text { Expensive, } \\
873 \text { obs., } \\
\text { adj. } R^{2}=0.84-0.86 \\
\text { Max VIF }=8.02\end{array}$ & $\begin{array}{l}-0.093 \\
(<0.001)\end{array}$ & $\begin{array}{l}-0.129 \\
(<0.001)\end{array}$ & $\begin{array}{l}0.0042 \\
(<0.001)\end{array}$ & $\begin{array}{l}0.0024 \\
(<0.001)\end{array}$ & $\begin{array}{l}-0.062 \\
(<0.001)\end{array}$ & $\begin{array}{l}-0.083 \\
(<0.001)\end{array}$ & $\begin{array}{l}0.0028 \\
(<0.001)\end{array}$ & $\begin{array}{l}0.0011 \\
(0.017)\end{array}$ \\
\hline $\begin{array}{l}\text { Cheap, } \\
872 \text { obs., } \\
\text { adj. } R^{2}=0.70-0.72 \\
\text { Max VIF = } 9.18\end{array}$ & $\begin{array}{l}-0.176 \\
(<0.001)\end{array}$ & $\begin{array}{l}-0.217 \\
(<0.001)\end{array}$ & $\begin{array}{l}0.0069 \\
(<0.001)\end{array}$ & $\begin{array}{l}0.0043 \\
(<0.001)\end{array}$ & $\begin{array}{l}-0.173 \\
(<0.001)\end{array}$ & $\begin{array}{l}-0.157 \\
(<0.001)\end{array}$ & $\begin{array}{l}0.0060 \\
(<0.001)\end{array}$ & $\begin{array}{l}0.0038 \\
(<0.001)\end{array}$ \\
\hline \multicolumn{9}{|l|}{$\mathrm{GWR}^{* *}$} \\
\hline $\begin{array}{l}\text { Overall average, } \\
4,362 \text { obs., } \\
\mathrm{R}^{2}=0.87-0.88\end{array}$ & $\begin{array}{l}-0.175 \\
(0.96)\end{array}$ & $\begin{array}{l}-0.235 \\
(0.97)\end{array}$ & $\begin{array}{l}0.0071 \\
(0.96)\end{array}$ & $\begin{array}{l}0.0049 \\
(0.95)\end{array}$ & $\begin{array}{l}-0.151 \\
(0.93)\end{array}$ & $\begin{array}{l}-0.159 \\
(0.97)\end{array}$ & $\begin{array}{l}0.0052 \\
(0.97)\end{array}$ & $\begin{array}{l}0.0040 \\
(0.91)\end{array}$ \\
\hline $\begin{array}{l}\text { Sainte-Foy-lès-Lyons, } \\
84 \text { obs. }\end{array}$ & $\begin{array}{l}-0.106 \\
(0.95)\end{array}$ & $\begin{array}{l}-0.169 \\
(1.00)\end{array}$ & $\begin{array}{l}0.0061 \\
(1.00)\end{array}$ & $\begin{array}{l}0.0025 \\
(0.87)\end{array}$ & $\begin{array}{l}-0.104 \\
(1.00)\end{array}$ & $\begin{array}{l}-0.127 \\
(1.00)\end{array}$ & $\begin{array}{l}0.0044 \\
(1.00)\end{array}$ & $\begin{array}{l}0.0022 \\
(0.99)\end{array}$ \\
\hline $\begin{array}{l}\text { Oullins, } \\
100 \text { obs. }\end{array}$ & $\begin{array}{l}-0.126 \\
(0.73)\end{array}$ & $\begin{array}{l}-0.173 \\
(0.83)\end{array}$ & $\begin{array}{l}0.0066 \\
(0.99)\end{array}$ & $\begin{array}{l}0.0018 \\
(0.56)\end{array}$ & $\begin{array}{l}-0.202 \\
(1.00)\end{array}$ & $\begin{array}{l}0.192 \\
(1.00)\end{array}$ & $\begin{array}{l}0.0088 \\
(1.00)\end{array}$ & $\begin{array}{l}0.0033 \\
(1.00)\end{array}$ \\
\hline $\begin{array}{l}\text { Vénissieux, } \\
97 \text { obs. }\end{array}$ & $\begin{array}{l}-0.169 \\
(0.90)\end{array}$ & $\begin{array}{l}-0.307 \\
(0.93)\end{array}$ & $\begin{array}{l}0.0105 \\
(1.00)\end{array}$ & $\begin{array}{l}0.0049 \\
(1.00)\end{array}$ & $\begin{array}{l}-0.322 \\
(1.00)\end{array}$ & $\begin{array}{l}-0.306 \\
(1.00)\end{array}$ & $\begin{array}{l}0.0125 \\
(1.00)\end{array}$ & $\begin{array}{l}0.0060 \\
(1.00)\end{array}$ \\
\hline $\begin{array}{l}\text { Vaulx-en-Velin, } \\
54 \text { obs. }\end{array}$ & $\begin{array}{l}-0.599 \\
(1.00)\end{array}$ & $\begin{array}{l}-0.505 \\
(1.00)\end{array}$ & $\begin{array}{l}0.0133 \\
(1.00)\end{array}$ & $\begin{array}{l}0.0070 \\
(1.00)\end{array}$ & $\begin{array}{l}-0.520 \\
(1.00)\end{array}$ & $\begin{array}{l}-0.398 \\
(1.00)\end{array}$ & $\begin{array}{l}0.0141 \\
(1.00)\end{array}$ & $\begin{array}{l}0.0080 \\
(1.00)\end{array}$ \\
\hline
\end{tabular}

Notes: * significance level is in the parentheses; $* *$ - percentage of cases significant at the $5 \%$ level is in the parentheses.

Concerning the geographically weighted results in Table 4, the average estimates among all the observations are reported as well as the four extractions from the examined suburbs taken from the overall GWR models. The absolute values of the average GWR estimates, which are a bit lower than the OLS results, increase from municipality to municipality in the sequence presented in Table 4. The only exception is that for the accessibility index for car in Oullins, whose coefficient is significant for only $56 \%$ of observations. In the eastern suburbs, the percentage of significant cases is always higher than 0.90 . Vaulx-en-Velin, where this percentage is always equal to unity, demonstrates the biggest difference from Sainte-Foy-lès-Lyons. The ratio of their coefficients is 5.7 for the travel time to Bellecour by car. The absolute values of the estimates for the western suburbs are, as a rule, lower than the GWR average, though Oullins is an exception in the three cases of public transport (travel times to Bellecour, City Hall and centrality index), which can be explained by relative underdevelopment of public transport at the time, for which the data have been collected. In the eastern suburbs, the absolute values of the accessibility estimates are almost always higher than the overall GWR averages.

\section{CONCLUSIONS}

The monocentric-based hypothesis that willingness to pay for better accessibility for the poor is higher than for the rich is empirically supported with a hedonic model of apartment prices. Monocentric models with travel times to two versions of city centre are supplemented with integral centrality and accessibility indexes. The results of hedonic models with different accessibility measures are quite similar. First, the hypothesis is supported with the cheap and expensive apartment segments. 
Second, the support is shown with the example of the suburbs representing the patterns of residential segregation: the inhabitants of poor suburbs are willing to pay several times more for the accessibility components of apartment price. Moreover, spatial differences in perception of accessibility are much higher than those between the expensive and cheap non-geographical apartment segments.

The spatial dispersion of observations in the examined four sub-samples is important, when the attributes within sub-sample are examined. Within one poor suburb, accessibility measures are found significant for public transport, but not for car. The GWR methodology allows comparing the effect between sub-samples in the overall model.

In the selected eastern Lyon suburbs we have not found, in general, poorer accessibility, especially when public transport is taken into account. What is really different is the willingness to pay for accessibility: the more socially problematic is the area, the higher is the price for better accessibility. This can be connected with lower car-ownership rate and other problems of disadvantaged neighbourhoods. From this viewpoint, the priority of public transport development in the eastern suburbs of Lyon looks reasonable as here its positive impact is more significantly capitalised in housing prices. Thus, investment in transport infrastructure in poor areas, which decreases travel time and simultaneously increases housing value, can be regarded in terms of economic efficiency and not only in those of social justice.

The standard theoretical model presented in the paper does not include location amenities other than the proximity to the CBD. Some empirical extension is possible with integral measures of centrality and accessibility considering service employment. In future study, more attention should be paid to other location amenities and their place in the trade-off with accessibility in the utility functions of household location choice of social groups. The techniques of Location Value Response Surface and Market Basket Value (McCluskey et al. 2000; Borst, McCluskey 2007; D'Amato 2010) can be potentially useful to identify value influence centres and to be applied as a stage of market segmentation.

\section{ACKNOWLEDGEMENTS}

This study is part of project PLAINSUDD sponsored through French ANR (number ANR-08VD-00). The authors are grateful to Perval and Pierre-Yves Péguy for providing data on apartment prices and attributes and to Nicolas Ovtracht for calculating the coordinates of apartment blocks and travel times with MOSART. The paper has been benefited from the discussions with Alain Bonnafous, Yves Crozet and Charles Raux as well as from valuable comments of anonymous reviewers.

\section{REFERENCES}

Alonso, W. 1964. Location and land use. Cambridge, MA: Harvard University Press.

Anas, A.; Arnott, R.; Small, K. A. 1998. Urban spatial structure, Journal of Economic Literature 36(3): 1426-1464.

Baltagi, B. H.; Bresson, G. 2011. Maximum likelihood estimation and Lagrange multiplier tests for panel seemingly unrelated regressions with spatial lag and spatial errors: an application to hedonic housing prices in Paris, Journal of Urban Economics 69(1): 24-42. http://dx.doi.org/10.1016/j.jue.2010.08.007

Bayer, P.; Ross, S. L.; Topa, G. 2008. Place of work and place of residence: informal hiring networks and labor market outcomes, Journal of Political Economy 116(6): 1150-1196. http://dx.doi.org/10.1086/595975

Bonnafous, A.; Crozet, Y.; Mercier, A.; Ovtracht, N.; Péguy, P. -Y.; Puech, F. 2011. MOSART et le projet PLAINSUDD: une plate-forme de modélisation et simulation de l'accessibilité pour l'aide à la décision et l'aménagement du territoire, in J.-P. Antoni (Ed.). Modéliser la ville: formes urbaines et politiques de transport. Paris: Economica, 186-210.

Borst, R.; McCluskey, W. 2007. Comparative evaluation of the comparable sales method with geostatistical valuation models, Pacific Rim Property Research Journal 13(1): 106-130.

Bouabdallah, K.; Cavaco, S.; Lesueur, J.-Y. 2002. Recherche d'emploi, contraintes spatiales et durée de chômage: une analyse microéconométrique, Revue d'Economie Politique 1: 137-157.

Bouzouina, L. 2008. Ségrégation spatial et dynamique métropolitaines. Thèse de Doctorat en Sciences Economique. Université Lumière Lyon 2.

Bouzouina, L. 2009 Densité et ségrégation socio-spatiale au sein des villes françaises, in F. Gaschet, C. Lacour (Eds.). Métropolisation et ségrégation. Bordeaux: Presses Universitaires de Bordeaux, 120-134,

Box, G. E. P.; Cox, D. 1964. An analysis of transformations, Journal of the Royal Statistical Society, Series B-Statistical Methodology 26(2): 211-252.

Buisson, M.-A.; Mignot, D. 2005 Concentration économique et ségrégation spatiale. Bruxelles: De Boeck.

Case, A. C.; Katz, L. F. 1991 The company you keep: the effect of family and neighborhood on disadvantaged youths, National Bureau Economic Research Working Papers, 3705.

Choffel, P.; Delattre, E. 2003. Habiter un quartier défavorisé: quels effets sur la durée de chômage?, Premières synthèses 43.1, Dares.

Goffette-Nagot, F.; Thomas, I.; Zenou, Y. 2000. Structure urbaine et revenus des ménages, in C. Baumont, P. Combes, P.-H. Derycke; H. Jayet (Eds.). Economie géographique: approches théoriques et empiriques. Paris: Economica, 276-302. 
Cutler, D.; Glaeser, E. 1997. Are ghettos good or bad?, Quarterly Journal of Economics 112(3): 827-872. http://dx.doi.org/10.1162/003355397555361

D'Amato, M. 2010. A location value response surface model for mass appraising: an "iterative" location adjustment factor in Bari, Italy, International Journal of Strategic Property Management 14(3): 231-244. http://dx.doi.org/10.3846/ijspm.2010.17

Fitoussi, J.-P.; Laurent, E.; Maurice, J. 2004. Ségrégation urbaine et intégration sociale. Rapport pour le Conseil de l'Analyse Economique. Paris: La Documentation Française.

Fitoussi, J.-P.; Savidan, P. 2003. Comprendre les inégalités. Paris: Presses Universitaires de France.

Follain, J. R.; Malpezzi, S. 1980. Estimates of housing inflation for 39 SMSAs: an alternative to the customer price index, Annals of Regional Science 14(3): 41-56. http://dx.doi.org/10.1007/BF01287312

Fujita, M. 1989. Urban economic theory: land use and city size. Cambridge, UK: Cambridge University Press.

Galster, G.; Andersson, R.; Musterd, S.; Kauppinen, T. M. 2008. Does neighborhood income mix affect earnings of adults? New evidence from Sweden, Journal of Urban Economics 63(3): 858-870. http://dx.doi.org/10.1016/j.jue.2007.07.002

Gaschet, F.; Gaussier, N. 2005. Les échelles du mauvais appariement spatial au sein de l'agglomération bordelaise, in M.-A. Buisson, D. Mignot (Eds.). Concentration économique et ségrégation spatiale. Bruxelles: De Boeck, 223-244.

Glaeser, E. L.; Kahn, M. E.; Rappaport, J. 2008. Why do the poor live in cities? The role of public transportation, Journal of Urban Economics 63(1): 1-24. http://dx.doi.org/10.1016/j.jue.2006.12.004

Gobillon, L.; Selod, H. 2004. Les déterminants spatiaux du chômage en Île-de-France, in J.-P. Fitoussi, E. Laurent, E. Maurice, (Eds.). Ségrégation urbaine et intégration sociale. Rapport pour le Conseil de l'Analyse Économique. Paris: La Documentation Française, 171-187.

Gouriéroux, C.; Laferrère, A. 2009. Managing hedonic housing price indexes: the French experience, Journal of Housing Economics 18(3): 206-213. http://dx.doi.org/10.1016/j.jhe.2009.07.012

Halvorsen, R.; Pollakowski, H. O. 1981. Choice of functional form for hedonic price equations, Journal of Urban Economics 10(1): 37-49. http://dx.doi.org/10.1016/0094-1190(81)90021-8

Helms, A. C. 2003. Understanding gentrification: an empirical analysis of the determinants of urban housing renovation, Journal of Urban Economics 54(3): 474498. http://dx.doi.org/10.1016/S0094-1190(03)00081-0

Hoxby, C. 2000. Peer effects in the classroom: learning from gender and race variation, National Bureau Economic Research Working Papers, 7867.

Kain, J. F. 1968. Housing segregation, Negro employment, and metropolitan decentralization, Quarterly Journal of Economics 82(2): 175-197. http://dx.doi.org/10.2307/1885893

Kim, H. M.; Kwan, M. P. 2003. Space-time accessibility measures: a geocomputational algorithm with a focus on the feasible opportunity set and possible activ- ity duration, Journal of Geographical Systems 5(1): 71-91. http://dx.doi.org/10.1007/s101090300104

Korsu, E.; Wenglenski, S. 2010. Job accessibility, residential segregation and risk of long-term unemployment in the Paris region, Urban Studies 47(11): 22792324. http://dx.doi.org/10.1177/0042098009357962

Krizek, K. J. 2005. Perspectives on accessibility and travel, in H. J. Miller, D. Levinson, K. J. Krizek (Eds.). Access to destinations. London: Elsevier, 109-130.

Kryvobokov, M. 2010. Is it worth identifying service employment (sub)centres when modelling apartment prices?, Journal of Property Research 27(4): 337-356. http://dx.doi.org/10.1080/09599916.2010.517852

LeRoy, S. F.; Sonstelie, J. 1983. Paradise lost and regained: transportation innovation, income and residential location, Journal of Urban Economics 13(1): 6789. http://dx.doi.org/10.1016/0094-1190(83)90046-3

Malpezzi, S. 2003. Hedonic pricing models: a selective and applied review, in A. O'Sullivan, K. Gibb (Eds.). Housing economics and public policy: essays in honor of Duncan Maclennan. Madler, MA: Blackwell, 67-85.

Maurin, E. 2004. Le ghetto français: Enquête sur le séparatisme social. Paris: La République des Idées, Le Seuil.

McCluskey, W. J.; Deddis, W. G.; Lamont, I. G.; Borst, R. A. 2000. The application of surface generated interpolation models for the prediction of residential property values, Journal of Property Investment and Finance 18(2): 162-176. http://dx.doi.org/10.1108/14635780010324321

McDonald, J. F. 1987. The identification of urban employment subcenters, Journal of Urban Economics 21(2): 242-258.

http://dx.doi.org/10.1016/0094-1190(87)90017-9

McDonald, J. F.; McMillen, D. P. 1990. Employment subcenters and land values in a polycentric urban area: the case of Chicago, Environment and Planning A 22(12): 1561-1574.

http://dx.doi.org/10.1068/a221561

McDonald, J. F.; Prather, P. J. 1994. Suburban employment centres: the case of Chicago, Urban Studies 31(2): 201-218. http://dx.doi.org/10.1080/00420989420080201

McMillen, D. P. 1996. One hundred fifty years of land values in Chicago: a nonparametric approach, Journal of Urban Economics 40(1): 100-124. http://dx.doi.org/10.1006/juec.1996.0025

McMillen, D. P.; Lester, T. W. 2003. Evolving subcenters: employment and population densities in Chicago, 1970-2020, Journal of Housing Economics 12(1): 6081. http://dx.doi.org/10.1016/S1051-1377(03)00005-6

Mignot, D.; Aguiléra, A.; Bloy, D.; Caubel, D.; Madre, J.-L. 2009. Formes urbaines, mobilités et ségrégation. Une comparaison Lille, Lyon et Marseille (France), Recherche Transports Sécurité 25/102: 47-59. http://dx.doi.org/10.3166/rts.102.47-59

Mills, E. S. 1967. An aggregate model of resource allocation in a metropolitan area, American Economic Review 57(2): 197-210.

Muth, R. F. 1969. Cities and housing. Chicago: The University of Chicago Press. 
Pan Ké Shon, J.-L. 2009. Ségrégation ethnique et ségrégation sociale en quartiers sensibles. L'apport des mobilités résidentielles, Revue Française de Sociologie 50(3): 451-487.

Pan Ké Shon, J.-L. 2010. The ambivalent nature of ethnic segregation in France's disadvantaged neighbourhoods, Urban Studies 47(8): 1603-1623. http://dx.doi.org/10.1177/0042098009356123

Rosen, S. 1974. Hedonic prices and implicit markets: product differentiation in pure competition, Journal of Political Economy 82(1): 34-55.

Ross, J. M.; Farmer, M. C.; Lipscomb, C. A. 2011. Inconsistency in welfare inferences from distance variables in hedonic regressions, Journal of Real Estate Finance and Economics 43(3): 385-400. http://dx.doi.org/10.1007/s11146-009-9221-z

Schnare, A.; Struyk, R. 1976. Segmentation in urban housing markets, Journal of Urban Economics 3(2): 146-166.

http://dx.doi.org/10.1016/0094-1190(76)90050-4

\section{APPENDIX 1}

\section{Centrality index and accessibility index}

A service centrality index for zone $i$ is calculated with a simple gravity-like model as an "objective" measure of potential access to opportunities:

$$
C I_{i}=\sum_{j=1}^{N} \frac{A_{j}}{t t_{i j}},
$$

where: $A_{j}$ - the attraction (service employment density) of zone $j ; t t_{i j}$ - the travel time from zone $i$ to zone $j ; N$ - the number of zones.

A service accessibility index is a "subjective" concept based on the realisation of potential access. Calculating this measure, we mainly follow the approach of Thériault et al. (2005). We estimate a suitability index applying fuzzy membership and using the $50^{\text {th }}$ percentile and $90^{\text {th }}$ percentile satisfaction thresholds from the household survey for home-to-shop travel times from the O-D matrix. A suitability index $S_{i j}$ for travelling from zone $i$ to zone $j$ is calculated as follows:

$$
\begin{aligned}
& S_{i j}=1 \quad \forall t t_{i j} \leq C_{50}, \\
& S_{i j}=1-\left(\frac{t t_{i j}-C_{50}}{C_{90}-C_{50}}\right) \forall C_{50}<t t_{i j}<C_{90}, \\
& S_{i j}=0 \quad \forall t t_{i j} \geq C_{90},
\end{aligned}
$$

Sivitanidou, R. 1996. Do office-commercial firms value access to service employment centres? A hedonic value analysis within polycentric Los Angeles, Journal of Urban Economics 40(2): 125-149. http://dx.doi.org/10.1006/juec.1996.0026

Thériault, M.; Des Rosiers, F.; Dubé, J. 2007. Testing the temporal stability of accessibility value in residential hedonic prices, Scienze Regionali 6(3): 5-46.

Thériault, M.; Des Rosiers, F.; Joerin, F. 2005. Modelling accessibility to urban services using fuzzy logic: a comparative analysis of two methods, Journal of Property Investment and Finance 23(1): 22-54. http://dx.doi.org/10.1108/14635780510575085

Wheaton, W. C. 1977. Income and urban residences: an analysis of consumer demand for location, American Economic Review 67(4): 620-631.

where: $t t_{i j}$ - the travel time from zone $i$ to zone $j ; C_{50}-$ the $50^{\text {th }}$ percentile of the observed travel time; $C_{90}$ - the $90^{\text {th }}$ percentile of the observed travel time.

The fuzzy membership function of the suitability index is graphically explained in Fig. A1.

A service accessibility index for zone $i$ is calculated as follows:

$$
A I_{i}=\sum_{j=1}^{N} S_{i j} A_{j},
$$

where: $S_{i j}$ - the suitability index for travelling from zone $i$ to zone $j ; A_{j}$ - the attraction of zone $j$; $N$ - the number of zones.

The values $C I_{i}$ and $A I_{i}$ for each zone are divided correspondingly by the maximum values in the area and multiplied by 100 .

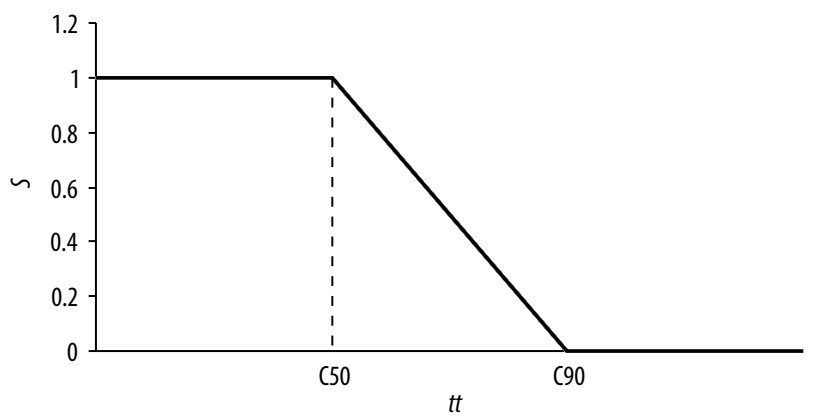

Fig. A1. The fuzzy membership function of the suitability index 


\section{APPENDIX 2}

\section{OLS and GWR models with TTBellecour by car}

\begin{tabular}{|c|c|c|c|c|}
\hline \multirow{2}{*}{$\begin{array}{l}\text { Variable, } \\
\text { parameter }\end{array}$} & \multicolumn{3}{|l|}{ OLS } & \multirow[t]{2}{*}{ GWR } \\
\hline & Overall & Expensive & Cheap & \\
\hline Constant & $4.552(<0.001)$ & $7.186(<0.001)$ & $6.947(<0.001)$ & 4.255 \\
\hline TTBellecour & $-0.224(<0.001)$ & $-0.093(<0.001)$ & $-0.176(<0.001)$ & -0.136 \\
\hline Year99 & $0.092(0.001)$ & $0.090(0.02)$ & $-0.087(0.26)$ & 0.062 \\
\hline Year00 & $0.162(<0.001)$ & $0.157(<0.001)$ & $-0.029(0.71)$ & 0.136 \\
\hline Year01 & $0.249(<0.001)$ & $0.281(<0.001)$ & $0.204(0.01)$ & 0.220 \\
\hline Year02 & $0.310(<0.001)$ & $0.330(<0.001)$ & $0.223(0.004)$ & 0.279 \\
\hline Year03 & $0.474(<0.001)$ & $0.485(<0.001)$ & $0.402(<0.001)$ & 0.451 \\
\hline Year04 & $0.633(<0.001)$ & $0.589(<0.001)$ & $0.590(<0.001)$ & 0.611 \\
\hline Year05 & $0.801(<0.001)$ & $0.748(<0.001)$ & $0.749(<0.001)$ & 0.764 \\
\hline Year06 & $0.933(<0.001)$ & $.801(<0.001)$ & $0.912(<0.001)$ & 0.897 \\
\hline Year07 & $1.011(<0.001)$ & $0.900(<0.001)$ & $1.055(<0.001)$ & 0.983 \\
\hline Year08 & $1.003(<0.001)$ & $0.916(<0.001)$ & $1.010(<0.001)$ & 0.963 \\
\hline Area & $0.932(<0.001)$ & $0.690(<0.001)$ & $0.383(<0.001)$ & 0.937 \\
\hline Bath2 & $0.094(<0.001)$ & $0.046(0.001)$ & $0.053(0.78)$ & 0.081 \\
\hline ParkUn & $0.092(<0.001)$ & $0.016(0.48)$ & $0.043(0.09)$ & 0.043 \\
\hline Park1 & $0.154(<0.001)$ & $0.039(0.20)$ & $0.090(0.001)$ & 0.099 \\
\hline Park2 & $0.193(<0.001)$ & $0.080(0.01)$ & $0.067(0.58)$ & 0.139 \\
\hline Floor1 & $0.067(<0.001)$ & $0.027(0.36)$ & $0.078(0.01)$ & 0.072 \\
\hline Floor2_4 & $0.104(<0.001)$ & $0.038(0.16)$ & $0.103(<0.001)$ & 0.118 \\
\hline Floor5_8 & $0.133(<0.001)$ & $0.073(0.01)$ & $0.134(<0.001)$ & 0.147 \\
\hline Floor9+ & $0.132(<0.001)$ & $0.166(0.002)$ & $0.194(0.01)$ & 0.165 \\
\hline Constr1850_1913 & $-0.092(<0.001)$ & $0.042(0.18)$ & $-0.119(0.01)$ & -0.083 \\
\hline Constr1914_1947 & $-0.082(<0.001)$ & $0.112(0.001)$ & $-0.110(0.01)$ & -0.062 \\
\hline Constr1948_1969 & $-0.153(<0.001)$ & $0.008(0.73)$ & $-0.122(0.002)$ & -0.119 \\
\hline Constr1970_1980 & $-0.123(<0.001)$ & $-0.005(0.83)$ & $-0.088(0.03)$ & -0.083 \\
\hline Constr1992< & $0.099(<0.001)$ & $0.099(<0.001)$ & $-0.085(0.12)$ & 0.104 \\
\hline CondMed & $-0.109(<0.001)$ & $0.009(0.63)$ & $-0.072(0.001)$ & -0.107 \\
\hline CondBad & $-0.215(<0.001)$ & $-0.092(0.04)$ & $-0.197(<0.001)$ & -0.225 \\
\hline ViewNo & $-0.040(<0.001)$ & $-0.027(0.03)$ & $-0.017(0.37)$ & -0.035 \\
\hline ViewBad & $-0.098(0.001)$ & $<0.001(0.99)$ & $-0.002(0.96)$ & -0.083 \\
\hline Cellar1 & $0.099(0.001)$ & $-0.002(0.88)$ & $0.092(<0.001)$ & 0.076 \\
\hline Cellar2 & $0.032(0.001)$ & $0.001(0.98)$ & $0.021(0.84)$ & -0.005 \\
\hline Garden & $0.049(0.02)$ & $-0.011(0.73)$ & $0.101(0.16)$ & 0.046 \\
\hline Terrace & $0.043(0.01)$ & $0.049(0.01)$ & $0.037(0.69)$ & 0.041 \\
\hline NewApartment & $0.046(0.01)$ & $-0.067(0.001)$ & $0.256(<0.001)$ & 0.047 \\
\hline District2 & $-0.109(<0.001)$ & $-0.035(0.01)$ & $-0.013(0.64)$ & -0.053 \\
\hline District3 & $-0.130(<0.001)$ & $-0.104(<0.001)$ & $0.021(0.54)$ & -0.088 \\
\hline District4 & $-0.229(<0.001)$ & $-0.188(0.01)$ & $0.093(0.01)$ & -0.189 \\
\hline \%MidIncome & $0.671(<0.001)$ & $0.313(0.05)$ & $0.558(0.01)$ & 0.770 \\
\hline \%HighIncome & $0.136(<0.001)$ & 0.097 & $0.029(0.61)$ & 0.028 \\
\hline Adjusted $\mathrm{R}^{2}$ & 0.838 & 0.839 & 0.705 & 0.875 \\
\hline N observations & 4,362 & 873 & 872 & 4,362 \\
\hline
\end{tabular}

Note: Significance level is in the parentheses. 


\section{APPENDIX 3}

\section{OLS and Spatial Error models for sumbarkets}

\begin{tabular}{|c|c|c|c|c|c|c|c|c|}
\hline \multirow[t]{2}{*}{ Submarket } & \multicolumn{4}{|c|}{ Accessibility by car } & \multicolumn{4}{|c|}{ Accessibility by public transport } \\
\hline & 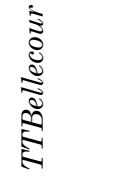 & 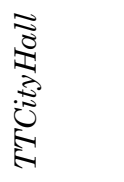 & 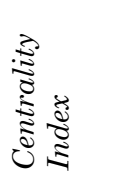 & 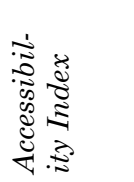 & 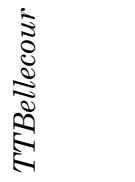 & 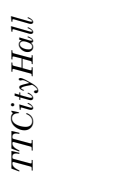 & 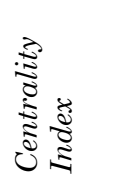 & 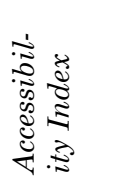 \\
\hline \multicolumn{9}{|l|}{ OLS } \\
\hline $\begin{array}{l}\text { Sainte-Foy-lès-Lyons, } \\
84 \text { obs., } \\
\text { adj. } R^{2}=0.83-0.84 \\
\text { Max VIF }=3.25\end{array}$ & $\begin{array}{l}-0.525 \\
(0.02)\end{array}$ & $\begin{array}{l}-0.381 \\
(0.11)\end{array}$ & $\begin{array}{l}0.022 \\
(0.12)\end{array}$ & $\begin{array}{l}0.006 \\
(0.06)\end{array}$ & $\begin{array}{l}-0.304 \\
(0.05)\end{array}$ & $\begin{array}{l}-0.203 \\
(0.21)\end{array}$ & $\begin{array}{l}0.013 \\
(0.19)\end{array}$ & $\begin{array}{l}0.003 \\
(0.13)\end{array}$ \\
\hline $\begin{array}{l}\text { Oullins, } \\
100 \text { obs., } \\
\text { adj. } R^{2}=0.88-0.89 \\
\text { Max VIF }=3.35\end{array}$ & $\begin{array}{l}0.098 \\
(0.62)\end{array}$ & $\begin{array}{l}0.306 \\
(0.25)\end{array}$ & $\begin{array}{l}-0.008 \\
(0.39)\end{array}$ & $\begin{array}{l}-0.003 \\
(0.33)\end{array}$ & $\begin{array}{l}0.307 \\
(0.18)\end{array}$ & $\begin{array}{l}0.396 \\
(0.03)\end{array}$ & $\begin{array}{l}-0.020 \\
(0.08)\end{array}$ & $\begin{array}{l}-0.005 \\
(0.06)\end{array}$ \\
\hline $\begin{array}{l}\text { Vénissieux, } \\
97 \text { obs., } \\
\text { adj. } \mathrm{R}^{2}=0.78-0.85, \\
\text { Max VIF }=5.56\end{array}$ & $\begin{array}{l}-0.237 \\
(0.17)\end{array}$ & $\begin{array}{l}-0.478 \\
(0.02)\end{array}$ & $\begin{array}{l}0.022 \\
(<0.001)\end{array}$ & $\begin{array}{l}0.006 \\
(<0.001)\end{array}$ & $\begin{array}{l}-0.935 \\
(<0.001)\end{array}$ & $\begin{array}{l}-0.911 \\
(<0.001)\end{array}$ & $\begin{array}{l}0.061 \\
(<0.001)\end{array}$ & $\begin{array}{l}0.013 \\
(<0.001)\end{array}$ \\
\hline $\begin{array}{l}\text { Vaulx-en-Velin, } \\
54 \text { obs., } \\
\text { adj. } R^{2}=0.66-0.68 \\
\text { Max VIF }=2.82\end{array}$ & $\begin{array}{l}1.970 \\
(0.19)\end{array}$ & $\begin{array}{l}0.016 \\
(0.99)\end{array}$ & $\begin{array}{l}-0.014 \\
(0.74)\end{array}$ & $\begin{array}{l}-0.005 \\
(0.69)\end{array}$ & $\begin{array}{l}0.559 \\
(0.54)\end{array}$ & $\begin{array}{l}-0.355 \\
(0.67)\end{array}$ & $\begin{array}{l}-0.007 \\
(0.87)\end{array}$ & $\begin{array}{l}-0.004 \\
(0.72)\end{array}$ \\
\hline \multicolumn{9}{|l|}{ Spatial Error } \\
\hline $\begin{array}{l}\text { Sainte-Foy-lès-Lyons, } \\
\mathrm{R}^{2}=0.88\end{array}$ & $\begin{array}{l}-0.599 \\
(0.01)\end{array}$ & $\begin{array}{l}-0.427 \\
(0.10)\end{array}$ & $\begin{array}{l}0.027 \\
(0.10)\end{array}$ & $\begin{array}{l}0.007 \\
(0.05)\end{array}$ & $\begin{array}{l}-0.486 \\
(0.01)\end{array}$ & $\begin{array}{l}-0.268 \\
(0.17)\end{array}$ & $\begin{array}{l}0.021 \\
(0.10)\end{array}$ & $\begin{array}{l}0.005 \\
(0.07)\end{array}$ \\
\hline $\begin{array}{l}\text { Oullins, } \\
\mathrm{R}^{2}=0.91\end{array}$ & $\begin{array}{l}0.117 \\
(0.59)\end{array}$ & $\begin{array}{l}0.311 \\
(0.27)\end{array}$ & $\begin{array}{l}-0.008 \\
(0.43)\end{array}$ & $\begin{array}{l}-0.003 \\
(0.35)\end{array}$ & $\begin{array}{l}0.318 \\
(0.18)\end{array}$ & $\begin{array}{l}0.422 \\
(0.02)\end{array}$ & $\begin{array}{l}-0.022 \\
(0.06)\end{array}$ & $\begin{array}{l}-0.005 \\
(0.05)\end{array}$ \\
\hline $\begin{array}{l}\text { Vénissieux, } \\
\mathrm{R}^{2}=0.87-0.89\end{array}$ & $\begin{array}{l}0.284 \\
(0.39)\end{array}$ & $\begin{array}{l}-0.260 \\
(0.45)\end{array}$ & $\begin{array}{l}0.022 \\
(0.04)\end{array}$ & $\begin{array}{l}0.005 \\
(0.11)\end{array}$ & $\begin{array}{l}-0.947 \\
(<0.001)\end{array}$ & $\begin{array}{l}-1.162 \\
(<0.001)\end{array}$ & $\begin{array}{l}0.061 \\
(<0.001)\end{array}$ & $\begin{array}{l}0.014 \\
(<0.001)\end{array}$ \\
\hline $\begin{array}{l}\text { Vaulx-en-Velin, } \\
\mathrm{R}^{2}=0.84\end{array}$ & $\begin{array}{l}0.147 \\
(0.94)\end{array}$ & $\begin{array}{l}-0.562 \\
(0.65)\end{array}$ & $\begin{array}{l}0.019 \\
(0.70)\end{array}$ & $\begin{array}{l}0.003 \\
(0.81)\end{array}$ & $\begin{array}{l}0.685 \\
(0.50)\end{array}$ & $\begin{array}{l}0.499 \\
(0.57)\end{array}$ & $\begin{array}{l}-0.008 \\
(0.86)\end{array}$ & $\begin{array}{l}-0.005 \\
(0.65)\end{array}$ \\
\hline
\end{tabular}

Note: Significance level is in the parentheses. 